\section{Students find out that bacteria can cheat too}

SIR — I shared S. P. Diggle and colleagues' Letter 'Cooperation and conflict in quorumsensing bacterial populations' (Nature 450, 411-414; 2007) with my ninth-grade mathematics students, because I was fascinated by the bacterial communication system known as 'quorum sensing' - as well as by exploitation in the prokaryotic realm.

I explained that even bacteria know how to assess their own numbers, which enables them to coordinate their behaviour and survival. The importance of mathematics and evidence of cheating in the world of bacteria could be compared with the case of a student who exploits the cooperative calculation of an answer to a specific algebraic problem set during, and resulting from, group work.

The discussion generated an opportunity for the students to identify certain similarities between bacterial behaviour and the dynamics of more complex organisms such as humans, and to show that mathematics is as ubiquitous as bacteria.

I have received positive feedback from parents encouraging the continued integration in the classroom of mathematics with other scientific disciplines and realworld scenarios. Thanks to the authors and to Nature for publishing a paper understandable to the average reader.

Nel C. Venzon, Jr

Mathematics Department, University Laboratory School, Curriculum Research and Development Group, University of Hawaii at Manoa, 1776 University Avenue, Honolulu, Hawaii 96822, USA

\section{European adventures did nothing for people of Egypt}

SIR - Napoleon's imperial project in Egypt was far from being romantic, as the headline on the Book Review of Nina Burleigh's Mirage: Napolean's scientists and the unveiling of Egypt would suggest ('The ultimate Romantic adventure' Nature 450, 793; 2007). Like other acts of imperialism, it was oppressive and demeaning to the lands and cultures that it claimed to liberate, study or civilize.

Did the learned men who were part of Napolean's imperial adventures ever wonder whether the often-brutal manipulation and subjugation of another civilization was in keeping with the highest ideals of the Enlightenment? Did any real benefit accrue to the peoples of Egypt or India when their treasures were revealed to Europe?

These wonders had been understood, interpreted and revered by the local populations within the context of their own culture and history long before Europeans came across them. Their 'discovery' by
Europeans largely paved the way for further exploitation. They filled the coffers of the colonial masters, but often impoverished the colonies. Looked at in isolation from the fundamentally unjust social and political policies that sustained them, the scientific achievements seem to be stunning. But any honest evaluation of the scientific byproducts of imperial projects is incomplete without acknowledgement of the exploitative nature of imperialism.

Ninad Bondre

Hornsey, London N8, UK

\section{Funding cuts leave 'golden era' looking tarnished}

SIR — Last May you ran an Editorial headlined 'Never had it so good?' (Nature 447, 231; 2007). "The Blair-Brown era has been a golden one for British science," it said. I found this surprising, as the nadir for R\&D funding (as a proportion of gross domestic product) over the past three decades occurred under the Blair government. Funding fell from $2.38 \%$ in 1981 to an average of $1.85 \%$ between 1997 (when Blair came to power) and 2003, according to the Organisation for Economic Co-operation and Development (OECD) Factbook 2006. UK funding remains well below the average, both in the 27 countries of the European Union and the 30 countries in the OECD.

I wasn't moved to write at that time, but the recent announcement by the UK Science and Technology Facilities Council of an $£ 80$-million (US\$156-million) shortfall in its budget (see Nature 450, 1127-1128; 2007) has made me change my mind. This is going to translate into a (minimum) $25 \%$ decrease in grants for the next three years, with no prospect of improvement after that - a situation that will be catastrophic for physics, astronomy and planetary science in the United Kingdom, and for the morale of those research communities. As a UK planetary scientist, this does not feel like a golden era. Phil Bland

Department of Earth Science and Engineering, Royal School of Mines, Imperial College London, South Kensington Campus, London SW7 2AZ, UK

\section{Future stars of the lab need realistic role models}

SIR - The Futures story 'When Britney Spears comes to my lab' (Nature 451, 106; 2008) was written tongue in cheek, but I am disappointed that Nature published it. Those of us who have decided "to put in more hours at the lab for the same reason all good scientists do" will resent being compared to even a fictional Ms Spears. Your article pokes fun at the pop singer, but it also indirectly undermines the dedication of real young women starting out on a research career.

The satirical Spears is helped in her scholarly endeavours by her pop-singer's salary, which exceeds that of a real graduate student by several orders of magnitude. Those who, like Spears, are parents must struggle on their stipends and balance the demands of scientific research with those of their children - not a problem for the wealthy Spears of academic fantasy.

Her frivolous appearance is also caricatured in the laboratory setting, reflecting an attitude that can still influence how women scientists dress. She also seems untroubled by the prospect of a fight for a place in the sciences. But that requires more than just inspiration: add quantities of caffeine, a fear of failure and years of hard work and personal sacrifice. I have yet to embark on the next step after graduate school, but I can only hope to have a fraction of the impact on society that the Dr Spears of Futures has on diabetes. I'll try to work harder.

I do agree, though, that we must find more ways to inspire upcoming generations to pursue endeavours that will benefit humanity, instead of glorifying reality television and tabloid superstardom. Sarah C. Hubbard

Department of Chemistry, B84 Hildebrand Hall, University of California, Berkeley, Berkeley, California 94720-1460, USA

\section{Freeing more carbon will accelerate global warming}

SIR - Although the Letter by D. M. Jones and colleagues, 'Crude-oil biodegradation via methanogenesis in subsurface petroleum reservoirs' (Nature 451, 176-180; 2008), describes fascinating science, the progression of this research to a viable technology would represent a dangerous advance in humankind's ability to accelerate global warming.

The prospect of increasing the energy efficiency of hydrocarbon extraction from tar sands, as referred to in the Letter, is highly questionable. Any technology that will increase our capacity to free surface or sub-surface carbon is surely undesirable, and will reduce the imperative to migrate to non-carbon or closed-carbon energy cycles. Neil Wilson

Camfridge Ltd, St John's Innovation Centre, Cowley Road, Cambridge CB4 OWS, UK

Contributions to this page may be submitted to correspondence@nature. com. We welcome comments on publishing issues at Nautilus (http://blogs.nature. com/nautilus). 